\author{
Andika Putri Pertiwi ${ }^{1}$ dan Ahmad Nursheha Gunawan ${ }^{2}$ \\ Program Studi Desain Interior \\ Universitas Telkom \\ 1 andkapertiwi@gmail.com \\ ªhmadnursheha@tcis.telkomuniversity.ac.id
}

\title{
PENGARUH KENYAMANAN VISUAL MELALUI PENCAHAYAAN BUATAN PADA MASJID SYAMSUL ULUM UNIVERSITAS TELKOM, BANDUNG
}

\begin{abstract}
Abstrak: Masjid merupakan sarana ibadah umat muslim yang dapat menampung jamaah dalam jumlah banyak, seiring waktu dan tuntutan kebutuhan aktifitas, masjid memiliki fungsi lain yang tidak hanya digunakan sebagai tempat beribadah tetapi juga sebagai sarana bersosialisasi baik secara vertikal maupun horizontal, permasalahan yang timbul adalah berkembangnya beragam aktivitas kegiatan dari peruntukan desain awal yang dibuat, salah satunya adalah konsep awal pencahayaan buatan yang diaplikasikan pada masjid dengan fungsi utama sebagai penunjang suasana sarana ibadah tidak dapat memberikan kenyamanan visual bagi user yang menggunakan masjid sebagai tempat kajian ilmu dan area untuk baca tulis al-quran. Penelitian yang dilakukan adalah jenis penelitian deskriptif kualitatif, yaitu pencarian fakta mengenai tingkat kenyamanan visual yang dipengaruhi pencahayaan buatan dengan objek penelitian ruang utama jamaah laki laki Masjid Syamsul Ulum Telkom University untuk penunjang kegiatan non ibadah seperti membaca dan menulis, dengan metode observasi, dokumentasi, wawancara dan pengukuran alat berupa luxmeter untuk mengetahui kualitas cahaya di beberapa titik yang dipetakan dengan pembagian area berdasarkan tingkat paparan cahaya pada area tersebut. Hasil observasi dan wawancara menunjukkan bahwa ukuran cahaya dalam ruangan masih jauh dibawah standar kenyamanan visual, pengguna yang beraktifitas di ruang utama jamaah laki-laki merasa pencahayaan buatan yang kurang memadai untuk aktifitas seperti membaca dan menulis. Hasil_pengukuran dengan alat luxmeter menunjukkan tingkat pencahayaan yang ada belum sesuai dengan standar penerangan minimal untuk sarana rumah ibadah dengan ketinggian ceiling diatas 6 meter adalah 200 lux dan untuk kegiatan belajar ruang kelas / perpustakaan beradadiantara 250-300 lux. Rekomendasi untuk memberi kenyamanan visual pada aktifitas membaca dan menulis adalah merancang tipe pencahayaan setempat (localize lighting) pada area bekerja visual spesifik yang membutuhkan intensitas cahaya lebih tinggi dengan colour temperature cool light. Sementara itu untuk area sholat tetap dapat menggunakan tipe pencahayaan merata (general lighting) dengan color temperature warm light yang menjadi aksen dengan tetap menggunakan colour temperature cool light sebagai renderasi cahaya utama.
\end{abstract}

Kata Kunci : Masjid Syamsul Ulum, sistem pencahayaan buatan, luxmeter

Abstract: Mosque is a Moslem religious facilities which can accomodate lot of people for praying, by the time Mosque had another function which not only used for praying but also used as a place to socialize either vertically or horizontally, the problems are when the preliminary design that has been made is not suitable with the variety of activities inside, such as artificial lighting concepts that applied on the mosque to support the ambience of humility in praying, can't provide the visual comforts for user who use the mosque as a place of Islamic studying and for tahsin \& tahfizh Quran too. The type of research would be conducted with qualitative description methodto find the fact, regarding the level of visual comforts that affected by an artificial lighting with proper interpretations according to the object of research which is the main hall of male prayers area at Masjid Syamsul Ulum Telkom 
University, by observing, documentating, interviewing and measurement tools such as luxmeter to know the quality of light at some points. The result from the observing and interviewing method shows that the light was below the standard of visual comfort, users inside the room of male prayers felt that the artificial lighting is lack to support their activities inside such as reading and writing. Meanwhile the measurment form luxmeter show that the artificial lighting intensity is not recomended for reading and writing activity which need higher intensity between 250-300 lux. To provide the comfort of artificial lighting for reading and writing activity is, designing localize lighting in the specific visual working area which is need highly light intensity with color temperature cool light. Meanwhile for the main area is using general lighting with color temperature warm light as an accent which combine with color temperature day light.

Keywords :Syamsul Ulum Mosque, artificial lighting, luxmeter

\section{$1 \quad$ Pendahuluan}

\subsection{Latar Belakang}

Masjid merupakan sarana ibadah umat muslim yang dapat menampung jamaah dalam jumlah banyak, namun seiring berjalannya waktu bangunan ini memiliki fungsi lain yang tidak hanya digunakan sebagai tempat peribadatan. Fungsi tersebut sering kita temui dalam studi kasus masjid yang terdapat di area kampus, seperti Masjid Syamsul Ulum Telkom University Bandung. Masjid Syamsul Ulum merupakan masjid kampus dengan berbagai kegiatan rohani mahasiswa muslim Telkom Universitybaik sebagai sentra kegiatan islam maupun sebagai tempat untuk kajian ilmu yang berlangsung hampir setiap hari mulai dari waktu subuh hingga pukul 21.00. Masjid Syamsul Ulum memiliki 3 zona utama yang biasa digunakan sebagai tempat ibadah maupun kegiatan lainnya yaitu ruang utama masjid, selasar/ serambi masjid, dan plaza masjid. Permasalahan yang timbul adalah ketika desain awal yang telah dibuat tidak sesuai dengan aktivitas yang semakin beragam dari waktu ke waktu, seperti konsep awal pencahayaan buatan yang diaplikasikan pada masjid dengan fungsi utama sebagai sarana ibadah, tidak dapat memberikan kenyamanan visual secara maksimal bagi pengguna masjid sebagai tempat kajian ilmu dan kegiatan baca tulis al-quran. Cahaya buatan merupakan salah satu elemen penting untuk mendukung kenyamanan visual dan produktifitas kerja pengguna bangunan terutama pada waktu sore hingga malam hari. Pengaplikasian cahaya buatan sesuai standar yang direkomendasikan akan berdampak dengan respon pengguna yang berbeda satu dan lainnya. Selain untuk mendukung aktifitas pengguna, cahaya buatan berfungsi untuk menimbulkan kesan tertentu, seperti pada Masjid Syamsul Ulum yang menggunakan pencahayaan buatan untuk memberikan kesan suasana hangat dengan penggunaan warna lampu warm light.Dari hasil pengamatan lapangan ditemukan pembagian zona pada ruang utama jamaah laki laki berdasarkan studi aktifitas yang membutuhkan spesifikasi jenis penerangan berbeda yaitu kegiatan yang membutuhkan penerangan general dan kegiatan yang membutuhkan penerangan spesifik. Oleh sebab itu perlu dilakukan penelitian terhadap kenyamanan visual melalui pencahayaan buatan terhadap berbagai aktifitas pengguna didalamnya baik aktifitas yang membutuhkan penerangan secara general maupun aktifitas yang membutuhkan penerangan lebih spesifik apakah sudah sesuai dengan fungsi masjid sebagai area khusus untuk beribadah atau dapat mempengaruhi kenyamanan visual untuk melakukan aktifitas lainnya seperti membaca al-quran dan kajian ilmu. 


\subsection{Kondisi Eksisting Pencahayaan Buatan pada Masjid Syamsul Ulum}

Konsep awal pencahayaan buatan Masjid Syamsul Ulum dimaksudkan untuk memunculkan kesan hangat pada ruangan, terlebih dengan penggunaan elemen interior berupa material kayu dengan nuansa warna coklat yang semakin menegaskan suasana hangat tersebut. Sementara itu, pada beberapa ruang seperti ruang utama jamaah perempuan dan selasar masjid sudah mengalami penambahan titik lampu dari kondisi awal bangunan. Berdasarkan hasil pengamatan pada ruang utama jamaah laki-laki dengan luasan $25 \mathrm{~m}$ x $25 \mathrm{~m}$ ditemukan beberapa kasus pengguna yang berkegitan hanya disatu area saja dengan kondisi penerangan yang cukup pada area tersebut sehingga penggunaan ruang menjadi kurang maksimal, karna pada area dengan pencahayaan minim jarang ditempati oleh pengguna dalam beraktifitas di dalam masjid.

\section{$2 \quad$ Kajian Literatur}

\subsection{Studi Komparasi Kondisi Kenyamanan Visual Ruang Ibadah Masjid}

Masjid merupakan bangunan dengan fungsi utama sarana peribadatan. Selain itu, masjid juga memiliki fungsi-fungsi sosial kemasyarakatan lainnya. Sebagai sarana peribadatan, masjid dituntut untuk mampu memfasilitasi ritual peribadatan di dalamnya, yaitu shalat, berdoa, dan mendengarkan ceramah (Diyarsyah, 2008). Untuk memenuhi tuntutan tersebut diperlukan perhatian pada 3 aspek. Pertama, aspek tingkat pencahayaan minimum yang memenuhi kebutuhan tugas visual tertentu. Kedua, aspek kenyamanan visual. Dan ketiga adalah aspek pemodelan dari permukaan-permukaan yang ada di dalam ruangan masjid. Aspek tingkat pencahayaan adalah tercukupinya horisontal minimum untuk tugas visual membaca, yaitu 100300 lux pada bidang kerja. Aspek kenyamanan visual dipengaruhi oleh kondisi kesilauan. Adapun aspek kepuasan visualisasi dipengaruhi oleh kontras luminansi dan rasio luminansi.

Parameter-parameter kenyamanan pencahayaan pada sebuah ruang ibadah masjid adalah tercukupinya tingkat pencahayaan horisontal minimum untuk tugas visual membaca sebesar 100 lux pada bidang kerja lantai, kontras yang tidak melebihi kontras ambang, kecerahan dalam batas normal serta luminansi obyek sumber cahaya yang tidak menyebabkan gangguan silau. Evaluasi dilakukan dengan menggunakan perangkat lunak Desktop Radiance 1.02. Data pengukuran memperlihatkan bahwa rentang tingkat pencahayaan alami siang hari antara 30,00â€"54,70 lux (Masjid PUSDAI), 14,00â€"176,00 lux (Masjid Salman ITB) dan 35,00â€"1020,00 lux (Masjid Raya Al Ukhuwah) sedangkan tingkat pencahayaan malam hari antara 3,30â€“44,10 lux (Masjid PUSDAI), 7,00â€“14,30 lux (Masjid Salman ITB) dan 12,00â€"110,00 lux (Masjid Raya Al Ukhuwah). Kenyamanan pencahayaan untuk tugas visual membaca hanya terpenuhi pada Masjid Raya Al Ukhuwah. Kontras luminansi obyek beberapa sumber cahaya pada ketiga masjid telah melebihi kontras ambang Bodmann yang berharga antara 0â€“0,5. Kecerahan yang melebihi 
batas terang Grafik Kecerahan Bodmann-Muck terjadi pada obyek beberapa luminair ruangan Masjid Al Ukhuwah pada malam hari namun untuk ketiga masjid tersebut, tidak ada sumber cahaya yang dapat mengakibatkan silau menurut standar Unified Glare Rating CIE. Hasil simulasi dengan perangkat lunak Desktop Radiance 1.02 juga menunjukkan bahwa kenyamanan pencahayaan pada ketiga masjid masih belum memenuhi standar CIE sehingga perlu dilakukan perbaikan-perbaikan (Evaluasi dan Perbaikan Kondisi Kenyamanan Pencahayaan pada Ruang Ibadah Masjid, 2007).

\subsection{Sistem Pencahayaan}

Dalam buku Fisika Bangunan 2 (2015) sistem pencahayaan dapat dikelompokkan menjadi :

a) Sistem pencahayaan merata (General Linghting)

Sistem ini memberikan tingkat pencahayaan yang merata di seluruh ruangan, digunakan jika tugas visual yang dilakukan di seluruh tempat dalam ruangan memerlukan tingkat pencahayaan yang sama.Tingkat pencahayaan yang merata diperoleh dengan memasang armatur secara merata langsung maupun tidak langsung di seluruh langit-langit. Layout luminer dan lampu tersebar merata agar tidak terjadi pemusatan efek lampu yang menyebabkan silau. Dalam memperoleh penerangan pada bidang kerja sesuai standar, beberapa lampu yang tersebar merata dengan intensitas cahaya secukupnya akan lebih baik dengan intensitas cahaya yang tinggi.

b) Sistem pencahayaan setempat (Localized Lighting)

Sistem ini memberikan tingkat pencahayaan pada bidang kerja yang tidak merata. Di tempat yang diperlukan untuk melakukan pekerjaan visual spesifikdengan tingkat pencahayaan yang tinggi. Hal ini diperoleh dengan mengkonsentrasikan penempatan armatur pada langit-langit di atas tempat tersebut. Intensitas cahaya lampu tidak bisa terlalu tinggi namun tetap memenuhi kebutuhan sesuai fungsi ruang, untuk itu arus cahaya lampu harus dibatasi dan desain luminer harus dipilih dengan tepat untuk mengantisipasi efek silau.

c) Sistem pencahayaan gabungan merata dan setempat.

Sistem pencahayaan gabungan didapatkan dengan menambah sistem pencahayaan setempat pada sistem pencahayaan merata, dengan armatur yang dipasang di dekat tugas visual. Sistem pencahayaan gabungan dianjurkan digunakan untuk : tugas visual yang memerlukan tingkat pencahayaan yang tinggi, memperlihatkan bentuk dan tekstur yang memerlukan cahaya datang dari arah tertentu, pencahayaan merata terhalang sehingga tidak dapat sampai pada tempat yang terhalang tersebut, tingkat pencahayaan yang lebih tinggi diperlukan untuk orang tua atau yang kemampuan penglihatannya sudah berkurang.

\subsection{Tampak Warna}



warnanya :

Sumber cahaya dapat dikelompokkan dalam 3 (tiga) kelompok menurut tampak

Tabel 1 .Tampak warna terhadap temperatur warna

\begin{tabular}{|c|c|}
\hline $\begin{array}{c}\text { Temperatur warna } \\
\text { K (Kelvin) }\end{array}$ & Tampak warna \\
\hline$>5300$ & - dingin \\
\hline $3300 \sim 5300$ & - sedang \\
\hline$<3300$ & - hangat \\
\hline
\end{tabular}

Sumber: SNI 03-2001

Pemilihan warna lampu bergantung kepada tingkat pencahayaan yang diperlukan agar diperoleh pencahayaan yang nyaman. Dalam menentukan kenyamanan visual, makin rendah kebutuhan penerangan dari cahaya lampu, maka colour temperature (CT) cahaya putih yang diterapkan makin rendah (warm white), sebaliknya, untuk kenyamanan visual, makin tinggi kebutuhan penerangan, colour temperature (CT) yang diterapkan semakin tinggi (cool white) (SNI 036575-2001, 2001). Kesan umum yang berhubungan dengan tingkat pencahayaan bermacammacam dan tampak warna yang berbeda dapat dilihat pada tabel dibawah ini.

Tabel 2 .Kaitan kuat penerangan dan colour temperature

\begin{tabular}{|c|c|c|c|}
\hline \multirow{2}{*}{$\begin{array}{c}\text { Tingkat } \\
\text { pencahayaan } \\
\text { Lux }\end{array}$} & \multicolumn{3}{|c|}{ Tampak warna lampu } \\
\cline { 2 - 4 } & Hangat & sedang & dingin \\
\hline$[500$ & Nyaman & Netral & dingin \\
\hline $500 \sim 1000$ & $\square$ & $\square$ & $\square$ \\
\hline $1000 \sim 2000$ & Stimulasi & Nyaman & Netral \\
\hline $2000 \sim 3000$ & $\square$ & $\square$ & $\square$ \\
\hline$\mu 3000$ & Tidak alami & Stimulasi & Nyaman \\
\hline
\end{tabular}

Sumber: SNI 03-2001

\subsection{Jenis Armatur}

Armatur adalah rumah lampu yang digunakan untuk mengendalikan dan mendistribusikan cahaya yang dipancarkan oleh lampu yang dipasang didalamnya. Klasifikasi berdasarkan cara pemasangan, armatur dapat dikelompokkan menjadi :

a. Armatur yang dipasang masuk ke dalam langit-langit ( ex. downlight, spotlight)

b. Armatur yang dipasang menempel pada langit-langit (ex. TL-RM, lampu baret)

c. Armatur yang digantung pada langit-langit ( ex. chandelier)

d. Armatur yang dipasang pada dinding (ex. pendant, lampu tembak)

Klasifikasi berdasarkan arah dan distribusi cahaya

Tabel 3 .Klasifikasi Armatur

\begin{tabular}{|l|c|c|}
\hline \multirow{2}{*}{ Kelas armatur } & \multicolumn{2}{c|}{ Jumlah cahaya } \\
\cline { 2 - 3 } & ke arah atas (\%) & ke arah bawah (\%) \\
\hline langsung & $0 \sim 10$ & $90 \sim 100$ \\
\hline semi langsung & $10 \sim 40$ & $60 \sim 90$ \\
\hline difus & $40 \sim 60$ & $40 \sim 60$ \\
\hline langsung-tidak langsung & $40 \sim 60$ & $40 \sim 60$ \\
\hline semi tidak langsung & $60 \sim 90$ & $10 \sim 40$ \\
\hline tidak langsung & $90 \sim 100$ & $0 \sim 10$ \\
\hline
\end{tabular}


Berdasarkan distribusi intensitas cahaya, armatur dapat dikelompokkan menurut presentase dari jumlah cahaya yang dipancarkan ke arah atas dan ke arah bawah bidang horisontal yang melewati titik tengah armatur.

\subsection{Persyaratan tingkat pencahayaan dalam ruang}

Berikut adalah table tingkat pencahayaan minimum dan renderasi warna yang direkomendasikan untuk rumah ibadah :

Tabel 4 .Tingkat pencahayaan minimum dan renderasi warna untuk rumah ibadah

\begin{tabular}{|l|c|c|l|}
\hline \multicolumn{1}{|c|}{ Fungsi ruangan } & $\begin{array}{c}\text { Tingkat } \\
\text { Pencahayaan } \\
\text { (lux) }\end{array}$ & $\begin{array}{c}\text { Kelompok } \\
\text { renderasi } \\
\text { warna }\end{array}$ & \multicolumn{1}{|c|}{ Keterangan } \\
\hline Rumah ibadah. & 200 & 1 atau 2 & $\begin{array}{l}\text { Untuk tempat-tempat yang mem } \\
\text { butuhkan tingkat pencahayaan } \\
\text { yang lebih tinggi dapat digunakan } \\
\text { pencahayaan setempat. }\end{array}$ \\
\hline Mesjid & 200 & 1 atau 2 & Idem \\
\hline Gereja & 200 & 1 atau 2 & idem \\
\hline Vihara & & & \\
\hline
\end{tabular}

Sumber: SNI 03-2001

Tabel 5 .Tingkat pencahayaan minimum dan renderasi warna yang direkomendasikan untuk lembaga pendidikan

\begin{tabular}{|l|c|c|l|}
\hline \multicolumn{1}{|c|}{ Fungsi ruangan } & $\begin{array}{c}\text { Tingkat } \\
\text { Pencahayaan } \\
\text { (lux) }\end{array}$ & $\begin{array}{c}\text { Kelompok } \\
\text { renderasi } \\
\text { warna }\end{array}$ & Keterangan \\
\hline Lembaga Pendidikan: & 250 & 1 atau 2 & \\
\hline Ruang kelas & 300 & 1 atau 2 & \\
\hline Perpustakaan & 500 & 1 & \\
\hline Laboratorium & 750 & 1 & $\begin{array}{l}\text { Gunakan pencahayaan setempat } \\
\text { pada meja gambar. }\end{array}$ \\
\hline Ruang gambar & 200 & 1 & \\
\hline Kantin & & & \\
\hline
\end{tabular}

Sumber: SNI 03-2001

\subsection{Faktor Layout Luminer dan Sumber Cahaya}

Dalam buku Fisika Bangunan 2, Faktor layout luminer dan sumber cahaya adalah sebagai berikut :
a. Fungsi ruang / aktifitas visual di dalamnya
b. Denah ruang dengan dimensi $\mathrm{P} \times \mathrm{L}$ x t (m) dan layout furnitur
c. Jumlah dan jenis luminer dan lampu 
d. Pengendalian dan pengeompokan penyalaan

e. Lokasi bukaan chaya untuk integrasi dengan PASH

f. Antisipasi efek silau.

\section{$3 \quad$ Metodologi Penelitian}

Jenis penelitian yang akan dilakukan adalah deskriptif kualitatif yaitu pencarian fakta mengenai tingkat kenyamanan visual yang dipengaruhi pencahayaan buatan dengan interpretasi yang tepat melalui pengamatan lapangan dan wawancara. Lokasi objek penelitian adalah Masjid Syamsul Ulum Telkom University, J1 Telekomunikasi no. 1 Terusan Buah Batu, Bandung, terdiri dari 2 lantai dengan fungsi utama sebagai tempat ibadah dan sentra kegiatan islam mahasiswa Telkom University. Sementara itu metode yang digunakan adalah pengolahan data seperti berikut

\subsection{Metode Observasi}

Melalui pengamatan interior Masjid Syamsul Ulum dan pengukuran tingkat penerangan menggunakan luxmeter dengan sample ruang utama jamaah laki laki yang terletak pada lantai satu.Variable yang digunakan dalam pengamatan adalah seputar persepsi pengguna dan aplikasi elemen pencahayaan buatan untuk beraktifitas dalam kondisi penerangan pencahayaan buatan.

- Jumlah dan jenis lampu yang digunakan ( meliputi besar watt, posisi pemasangan, jenis penyinaran, warna lampu).

- Jenis luminer yang digunakan (meliputi kesan cahaya yang ditimbulkan, ketinggian pemasangan, dan letak pemasangan.

- Elemen Interior yang memantulkan cahaya buatan ( Luas ruangan dan fungsi ruang, Tinggi ceilling, material dinding, lantai dan langit langit, warna elemen interior).

- Aktifitas pengguna yang berlangsung dari pukul 12.00 - 21.00 ( zona kegiatan, durasi kegiatan dalam ruangan, jenis kegiatan, alur kegiatan).

\subsection{Metode Interview}

Dilakukan untuk mengetahui persepsi pengguna terhadap kenyamanan visual dalam beraktifitas, dengan narasumber mahasiswa dan mahasiswi yang berada pada zona sample, jumlah responden sebanyak 30 orang, dengan rincian pertanyaan sebagai berikut:

- Waktu-waktu berkunjung ke Masjid Syamsul Ulum

- Kegiatan yang sering dilakukan di Masjid Syamsul Ulum (selain sholat) pada waktu tersebut

- Area pada ruang utama Masjid Syamsul Ulum yang sering ditempati ketika melaksanakan kegiatan tersebut berdasarkan titik yang telah ditentukan beserta alasannya. 
- Terang atau tidaknya kesan pencahayaan pada titik yang ditempati untuk melakukan kegiatan selain ibadah.

- Deskripsi suasana pencahayaan buatan pada sore hingga malam hari berdasarkan persepsi pengguna secara visual.

\subsection{Metode Analisis Data}

Analisa data berdasarkan observasi melalui pengukuran tingkat penerangan cahaya buatan pada waktu malam hari menggunakan luxmeter, dilakukan di beberapa titik ruang utama jamaah laki-laki dengan pembagian zona ibadah yang membutuhkan general lighting dan zona kegiatan khusus yang membutuhkan localize lighting. Ruang utama masjid dibagi menjadi 25 titik dengan spekulasi 13 titik untuk kegiatan bekerja visual spesifik yang membutuhkan localize lighting, dan 12 titik untuk kegiatan ibadah yang hanya membutuhkan general lighting,. Pengukuran tingkat penerangan zona ibadah dilakukan pada titik 14-25, Sementara itu pengukuran tingkat penerangan zona kegiatan khusus dilakukan pada titik 1 - 13 .

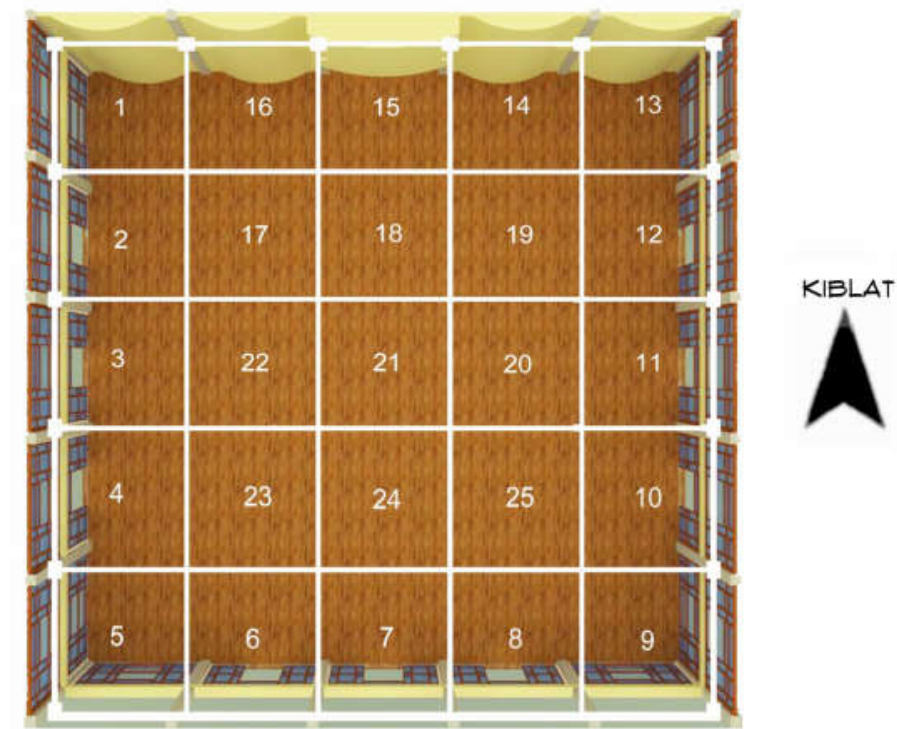

Gambar 1 .Titik pengukuran luxmeter dengan radius $25 \mathrm{~m}^{2}$ sumber : pribadi

\section{$4 \quad$ Hasil dan Pembahasan}

\subsection{Subjek Penelitian}

Berdasarkan hasil wawancara yang dilakukan terhadap 30 orang pengguna masjid yang berkegiatan diwaktu sore hingga malam hari pada tanggal 1 September 2016, data yang didapat 
berupa respon kondisi pencahayaan buatan dalam ruangan pada kegiatan selain aktifitas sholat adalah sebagai berikut:

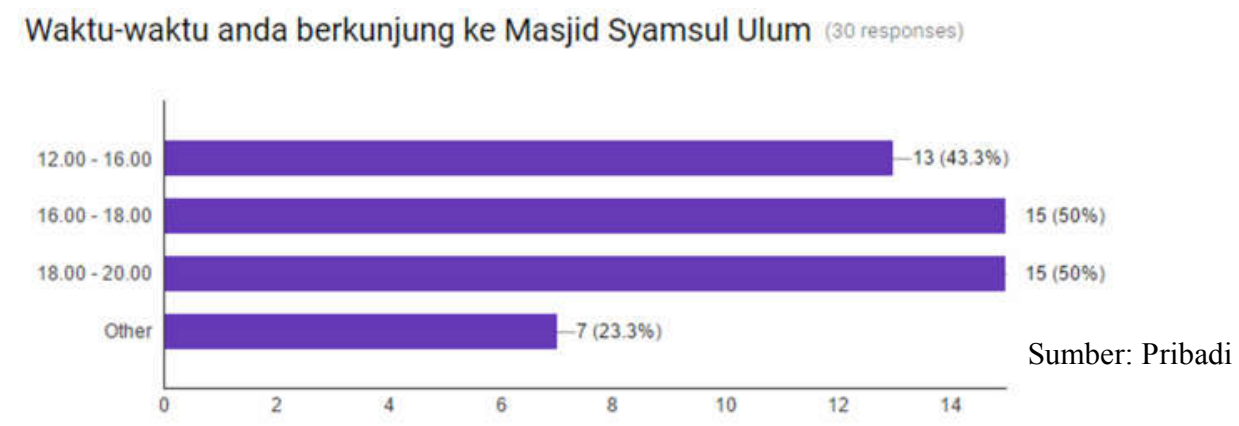

Diagram 1. Grafik hasil interview pengguna

Kegiatan yang sering anda lakukan di Masjid Syamsul Ulum (selain sholat) pada jam-jam tersebut (30 responses)

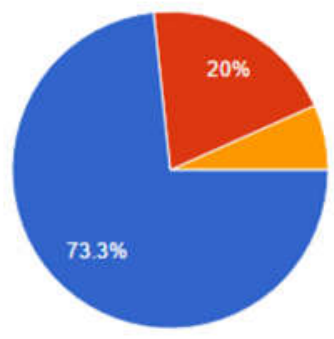

Diskusi (ex: kajian, mentoring )

- Tadarus quran / Membaca buku

- Belajar kelompok/Mengerjakan

tugas

Diagram 2. Grafik hasil interview

Apakah kesan pencahayaan pada titik yang anda tempati untuk melakukan kegiatan selain ibadah sudah cukup terang?

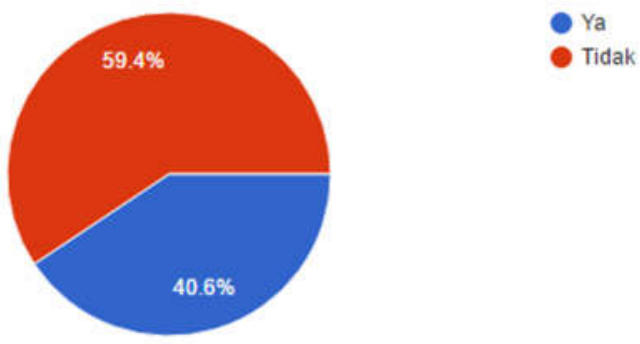

Sumber: Pribadi

Diagram 3. Grafik hasil interview

Dari hasil analisa data dapat disimpulkan bahwa pengguna sebagian besar berkunjung ke masjid pada pukul 16.00- 20.00 WIBuntuk melakukan kegiatan diskusi dan tadarus al-quran, sementara itu 59,4\% atau sebanyak 19 orang dari jumlah total 30 responden mengatakan bahwa 
kesan pencahayaan pada area pengguna yang dibagi kedalam 25 titik belum cukup terang dalam melakukan kegiatan visual spesifik seperti diskusi dan membaca al-quran.

\subsection{Objek Penelitian}

Ruang utama jamaah laki-laki terdiri dari area mihrab dan area jamaah, dengan luas ruangan $25 \times 25 \mathrm{~m}$ dan tinggiceilling $6 \mathrm{~m}$, material pada lantai menggunakan parquet kayu mahoni dengan warna coklat kemerahan, material pada ceilling menggunakan profil kayu jati dengan warna yang sama dan untuk material dinding menggunakan finishing cat tembok water based berwarna coklat muda. Dengan zona aktifitas ibadah terdapat di tengah-tengah ruangan dan aktifitas lainnya berada di sisi ruangan, kegiatan-kegiatan yang sering berlangsung diantaranya :kajian ilmu, kegiatan tahsin dan tahfidz (membaca dan menghafal quran), mentoring dan belajar kelompok.

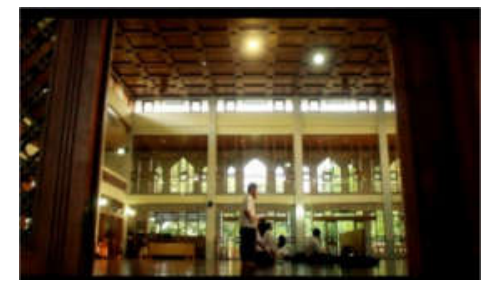

Gambar 2.Kondisi penerangan pada waktu siang hari (sumber : pribadi)

Zona Ibadah zona aktifitas lain

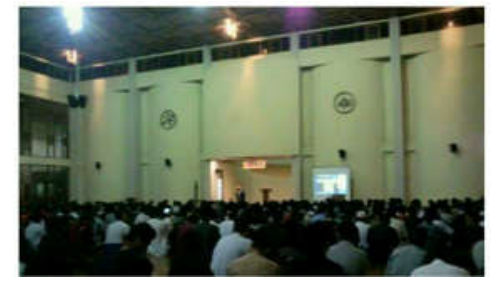

Gambar 3.Kondisi penerangan pada waktu subuh ketika kajian (sumber : pribadi)

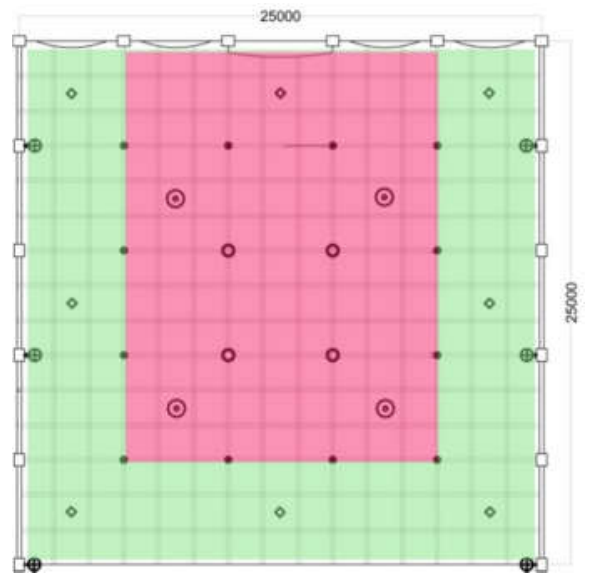

Gambar 5. Zoning ruang ibadah laki-laki beserta perletakan titik lampu kondisi eksisting sumber : pribadi

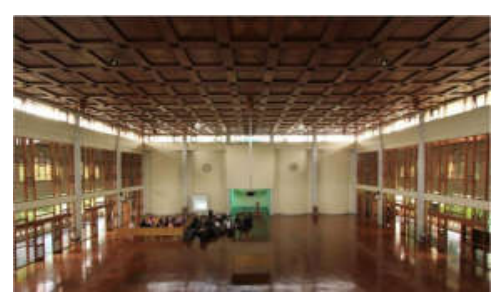

Gambar 4. Kondisi interior masjid (sumber : pribadi)

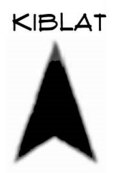


Zona ibadah yang berada ditengah ruangan menggunakan tipe penerangan general lighting dengan intensitas cahaya rata-rata 22.00 lux yang diukur dari beberapa titik, sementara itu berdasarkan sumber dari SNI 03-2001standar penerangan minimal untuk sarana rumah ibadah dengan ketinggian ceiling diatas 6 meter adalah 200 lux dan untuk kegiatan belajar ruang kelas / perpustakaan berada diantara 250-300 lux. Dari hasil pengamatan lapangan dan wawancara terhadap pengguna, zona aktifitas lain yang berada disisi bangunan, sering digunakan untuk kegiatan bekerja visual spesifik seperti membaca dan menghafal al-quran, pada area tersebut jenis pencahayaan yang digunakan adalah penerangan general lighting.

Tabel 6 .Aplikasi lampu pada ruang utama jamaah pria

\begin{tabular}{|c|c|c|c|c|}
\hline $\begin{array}{c}\text { Dokumentasi } \\
\text { Lapangan }\end{array}$ & $\begin{array}{l}\text { Notasi Lampu } \\
\text { pada denah }\end{array}$ & $\begin{array}{l}\text { Jenis Lampu dan } \\
\text { armature }\end{array}$ & $\begin{array}{c}\text { Warna lampu dan } \\
\text { kesan yang } \\
\text { ditimbulkan }\end{array}$ & Keterangan \\
\hline & () & $\begin{array}{l}\text { Floerescent tipe } \\
\text { CFL cool light } \\
\text { dengan armature } \\
\text { chandelier bulat }\end{array}$ & \multirow{3}{*}{$\begin{array}{c}\text { Warna putih } \\
\text { menimbulkan } \\
\text { kesan jelas dan } \\
\text { dingin }\end{array}$} & $\begin{array}{l}\text { Jumlah } 4 \text { titik } \\
\text { lampu dengan } \\
\text { posisi ditengah } \\
\text { ruangan }\end{array}$ \\
\hline & (0) & $\begin{array}{l}\text { Floerescent tipe } \\
\text { CFL cool light } \\
\text { dengan armature } \\
\text { piringan }\end{array}$ & & $\begin{array}{l}\text { Jumlah } 4 \text { titik } \\
\text { lampu dengan } \\
\text { posisi ditengah } \\
\text { ruangan }\end{array}$ \\
\hline & $\otimes$ & $\begin{array}{c}\text { LED cool light } 9 \mathrm{~W} \\
\text { dengan armature } \\
\text { downlight }\end{array}$ & & $\begin{array}{l}\text { Jumlah } 16 \text { titik } \\
\text { lampu dengan } \\
\text { posisi menyebar }\end{array}$ \\
\hline & $\diamond$ & $\begin{array}{l}\text { FL warm light tipe } \\
\text { armatur custom }\end{array}$ & $\begin{array}{l}\text { Warna kuning } \\
\text { menimbulkan } \\
\text { kesan hangat } \\
\text { dalam ruangan }\end{array}$ & $\begin{array}{l}\text { Jumlah } 8 \text { titik } \\
\text { lampu dengan } \\
\text { posisi di sisi } \\
\text { ruangan }\end{array}$ \\
\hline & $\oplus$ & $\begin{array}{l}\text { Floerescent tipe } \\
\text { CFL dengan } \\
\text { armature lampu } \\
\text { dinding bulat }\end{array}$ & $\begin{array}{c}\text { Warna putih } \\
\text { menimbulkan kesan } \\
\text { jelas dan dingin }\end{array}$ & $\begin{array}{l}\text { Jumlah } 12 \text { titik } \\
\text { lampu dengan } \\
\text { posisi menempel } \\
\text { di kolom. }\end{array}$ \\
\hline
\end{tabular}




\subsection{Hasil Pengukuran}

Pengukuran dilakukan pada 25 titik dengan radius $25 \mathrm{~m}^{2}$ di ruang utama jamaah laki-laki Masjid Syamsul Ulum Telkom University pada pukul 21.00 s/d 22.00 WIB. Pengukuran dibagi kedalam 2 area, yaitu area untuk kegiatan khusus dan area untuk tempat ibadah, dalam pengukuran intensitas cahaya ada beberapa faktor yang menjadi pertimbangan utama sebagai berikut :

- Jenis lampu dan jenis luminer terdekat dalam radius $25 \mathrm{~m}^{2}$ pada titik pengukuran yang akan mempengaruhi tinggi rendahnya intensitas.

- Pada titik tertentu yang letaknya dekat dengan komponen jendela, tentu akan memiliki intensitas cahaya lebih rendah dibandingkan titik yang berada ditengah ruangan, dapat disebabkan karena material kaca pada jendela yang memungkinkan cahaya untuk berpendar ke luar ruangan, sehingga hasil pengukuran intensitas cahaya pada setiap titik akan berbeda beda.

- Material interior pada ruangan dapat mempengaruhi persepsi pengguna dalam menilai tingkat kecerahan ruang, sementara itu sifat material yang licin pada ruang dapat menyebabkan efek pantul cahaya pada saat proses pengukuran.

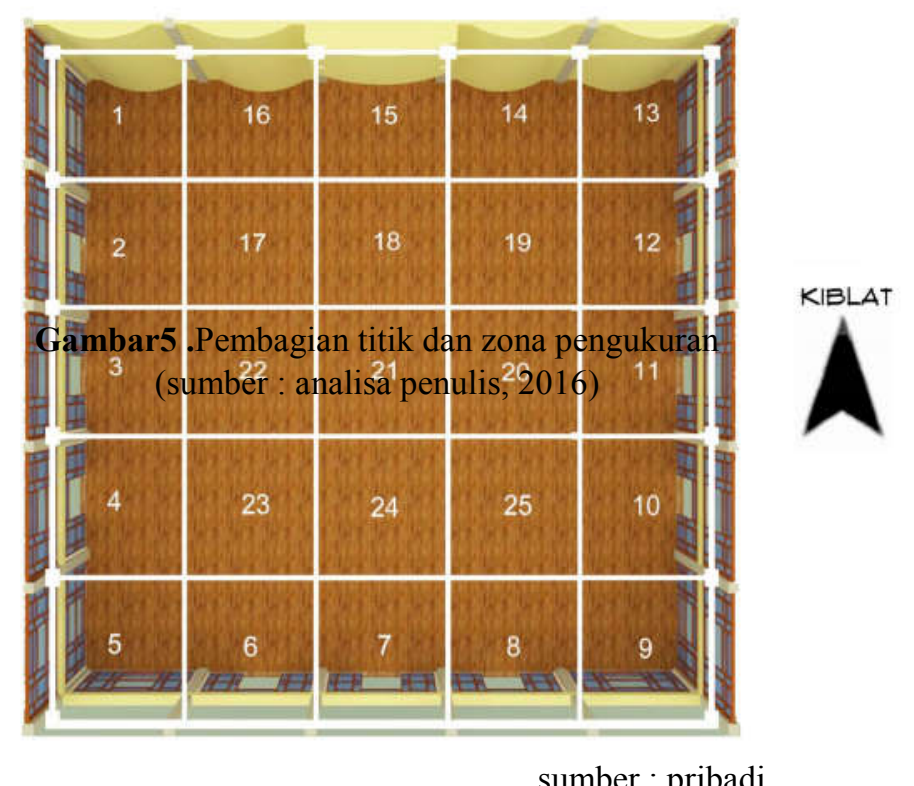

Diketahui zona kegiatan khusus terletak pada titik 1 sampai dengan titik 13 dengan luas area keseluruhan $325 \mathrm{~m}^{2}$. Dari hasil pengamatan lapangan, titik yang mendapatkan tingkat kecerahan lebih tinggi adalah titik nomor 4,6,8 dan 10 disebabkan area tersebut mendapatkan pancaran cahaya lampu tembak dari ruang utama jamaah perempuan. Sementara itu zona kegiatan ibadah yang terletak pada titik 14 sampai dengan titik 25, mendapatkan tingkat penerangan yang lebih tinggi disebabkan oleh letak zona yang jauh dari komponen jendela pada 


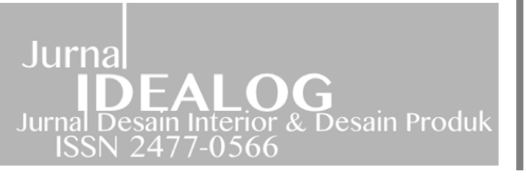

sisi ruang. Dari spekulasi tersebut maka akan dilakukan pengukuran secara keseluruhan pada ruang utama jamaah laki laki yang dibagi kedalam 2 zona menggunakan alat bantu berupa luxmeter, dalam pengukuran lapangan terdapat dua variabel yang digunakan dalam proses pengambilan data yaitu:

1. Jenis lampu yang terdapat disekitar titik pengukuran dengan radius $25 \mathrm{~m}^{2}$

2. Jenis armatur berdasarkan arah cahaya.

dengan hasil pengukuran sebagai berikut :

Tabel 7 .Hasil pengukuran dan analisa tingkat penerangan ruang utama jamaah pria dengan lux meter

(sumber : analisa penulis, 2016)

\begin{tabular}{|c|c|c|c|}
\hline \multicolumn{4}{|c|}{ Zona Kegiatan Khusus (capaian intensitas minimal 250 lux) } \\
\hline $\begin{array}{c}\text { Nomor } \\
\text { Titik }\end{array}$ & $\begin{array}{l}\text { Hasil Pengukuran } \\
\text { Lapangan (lux) }\end{array}$ & $\begin{array}{l}\text { Jenis lampu yang terdapat disekitar } \\
\text { titik pengukuran dengan radius } 25 \mathrm{~m}^{2}\end{array}$ & $\begin{array}{c}\text { Jenis armatur } \\
\text { berdasarkan arah cahaya }\end{array}$ \\
\hline 1 & $14.50 \operatorname{lux}$ & $\begin{array}{l}\text { LED cool light } 9 \mathrm{~W} \\
\text { FL warm light } \\
\text { FL cool light }\end{array}$ & $\begin{array}{c}\text { Langsung } \\
\text { Semi langsung } \\
\text { Semi tidak langsung }\end{array}$ \\
\hline 2 & $14.12 \operatorname{lux}$ & $\begin{array}{l}2 \text { LED cool light } 9 \mathrm{~W} \\
\text { FL cool light }\end{array}$ & $\begin{array}{c}\text { Langsung } \\
\text { Semi tidak langsung }\end{array}$ \\
\hline 3 & $16.48 \operatorname{lux}$ & $\begin{array}{c}2 \text { LED cool light } 9 \mathrm{~W} \\
\text { FL cool light } \\
\text { FL warm light }\end{array}$ & $\begin{array}{c}\text { Langsung } \\
\text { Semi tidak langsung } \\
\text { Semi langsung }\end{array}$ \\
\hline 4 & $21.27 \operatorname{lux}$ & $\begin{array}{c}2 \text { LED cool light } 9 \mathrm{~W} \\
\text { FL cool light } \\
\text { Halogen (lampu tembak) }\end{array}$ & $\begin{array}{c}\text { Langsung } \\
\text { Semi tidak langsung } \\
\text { langsung }\end{array}$ \\
\hline 5 & $18.56 \operatorname{lux}$ & $\begin{array}{l}\text { LED cool light } 9 \mathrm{~W} \\
\text { FL warm light } \\
\text { FL cool light }\end{array}$ & $\begin{array}{c}\text { Langsung } \\
\text { Semi langsung } \\
\text { Semi tidak langsung }\end{array}$ \\
\hline 6 & $30.22 \operatorname{lux}$ & $\begin{array}{l}\text { 2 LED cool light } 9 \mathrm{~W} \\
\text { Halogen (lampu tembak) }\end{array}$ & $\begin{array}{l}\text { Langsung } \\
\text { langsung }\end{array}$ \\
\hline 7 & $27.55 \operatorname{lux}$ & $\begin{array}{l}2 \text { LED cool light } 9 \mathrm{~W} \\
\text { FL warm light }\end{array}$ & $\begin{array}{c}\text { Langsung } \\
\text { Semi langsung }\end{array}$ \\
\hline 8 & $35.09 \operatorname{lux}$ & $\begin{array}{l}2 \text { LED cool light } 9 \mathrm{~W} \\
\text { Halogen (lampu tembak) }\end{array}$ & $\begin{array}{l}\text { Langsung } \\
\text { langsung }\end{array}$ \\
\hline 9 & $19.15 \operatorname{lux}$ & $\begin{array}{l}\text { LED cool light } 9 \mathrm{~W} \\
\text { FL warm light }\end{array}$ & $\begin{array}{c}\text { Langsung } \\
\text { Semi langsung }\end{array}$ \\
\hline 10 & $21.17 \operatorname{lux}$ & $\begin{array}{l}2 \text { LED cool light } 9 \mathrm{~W} \\
\text { FL cool light }\end{array}$ & $\begin{array}{c}\text { Langsung } \\
\text { Semi tidak langsung }\end{array}$ \\
\hline 11 & $19.14 \operatorname{lux}$ & $\begin{array}{c}2 \text { LED cool light } 9 \mathrm{~W} \\
\text { FL cool light } \\
\text { FL warm light }\end{array}$ & $\begin{array}{c}\text { Langsung } \\
\text { Semi tidak langsung } \\
\text { Semi langsung }\end{array}$ \\
\hline 12 & $19.21 \operatorname{lux}$ & $\begin{array}{l}2 \text { LED cool light } 9 \mathrm{~W} \\
\text { FL cool light }\end{array}$ & $\begin{array}{c}\text { Langsung } \\
\text { Semi tidak langsung }\end{array}$ \\
\hline
\end{tabular}




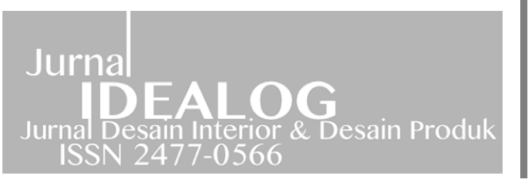

\begin{tabular}{|c|c|c|c|}
\hline 13 & $13.45 \operatorname{lux}$ & $\begin{array}{c}\text { LED cool light } 9 \mathrm{~W} \\
\text { FL warm light } \\
\text { FL cool light }\end{array}$ & $\begin{array}{c}\text { Langsung } \\
\text { Semi langsung } \\
\text { Semi tidak langsung }\end{array}$ \\
\hline \multicolumn{4}{|c|}{ Zona Kegiatan Ibadah (capaian intensitas minimal 200 lux) } \\
\hline $\begin{array}{l}\text { Nomor } \\
\text { Titik }\end{array}$ & $\begin{array}{l}\text { Hasil Pengukuran } \\
\text { Lapangan (lux) }\end{array}$ & $\begin{array}{l}\text { Jenis lampu yang terdapat disekitar } \\
\text { titik pengukuran dengan radius } 25 \mathrm{~m}^{2}\end{array}$ & $\begin{array}{c}\text { Jenis armatur } \\
\text { berdasarkan arah cahaya }\end{array}$ \\
\hline 14 & $18.58 \operatorname{lux}$ & 2 LED cool light $9 \mathrm{~W}$ & Langsung \\
\hline 15 & $26.80 \operatorname{lux}$ & $\begin{array}{l}2 \text { LED cool light } 9 \mathrm{~W} \\
\text { FL cool light }\end{array}$ & $\begin{array}{l}\text { Langsung } \\
\text { Semi tidak langsung }\end{array}$ \\
\hline 16 & $18.83 \operatorname{lux}$ & 2 LED cool light $9 \mathrm{~W}$ & Langsung \\
\hline 17 & 19.07 lux & $\begin{array}{c}\text { 3LED cool light } 9 \mathrm{~W} \\
\text { FL cool light } \\
\text { FL cool light }\end{array}$ & $\begin{array}{l}\text { Langsung } \\
\text { difus } \\
\text { Langsung }\end{array}$ \\
\hline 18 & $28.33 \operatorname{lux}$ & $\begin{array}{l}2 \text { LED cool light } 9 \mathrm{~W} \\
2 \text { FL cool light }\end{array}$ & $\begin{array}{l}\text { Langsung } \\
\text { difus }\end{array}$ \\
\hline 19 & $22.75 \operatorname{lux}$ & $\begin{array}{c}\text { 3LED cool light } 9 \mathrm{~W} \\
\text { FL cool light } \\
\text { FL cool light }\end{array}$ & $\begin{array}{l}\text { Langsung } \\
\text { difus } \\
\text { Langsung } \\
\end{array}$ \\
\hline 20 & $25.08 \operatorname{lux}$ & $\begin{array}{l}2 \text { LED cool light } 9 \mathrm{~W} \\
2 \text { FL cool light }\end{array}$ & $\begin{array}{l}\text { Langsung } \\
\text { difus }\end{array}$ \\
\hline 21 & $32.17 \operatorname{lux}$ & 4 FL cool light & Difus \\
\hline 22 & $26.15 \operatorname{lux}$ & $\begin{array}{l}2 \text { LED cool light } 9 \mathrm{~W} \\
2 \mathrm{FL} \text { cool light }\end{array}$ & $\begin{array}{c}\text { Langsung } \\
\text { difus }\end{array}$ \\
\hline 23 & $20.37 \operatorname{lux}$ & $\begin{array}{l}\text { 3LED cool light } 9 \mathrm{~W} \\
\text { FL cool light }\end{array}$ & $\begin{array}{l}\text { Langsung } \\
\text { difus }\end{array}$ \\
\hline 24 & $23.56 \operatorname{lux}$ & $\begin{array}{c}2 \text { FL cool light } \\
2 \text { LED cool light } 9 \mathrm{~W}\end{array}$ & $\begin{array}{c}\text { Difus } \\
\text { Langsung }\end{array}$ \\
\hline 25 & $22.17 \operatorname{lux}$ & $\begin{array}{l}\text { 3LED cool light } 9 \mathrm{~W} \\
\text { FL cool light }\end{array}$ & $\begin{array}{l}\text { Langsung } \\
\text { difus }\end{array}$ \\
\hline
\end{tabular}

Dari data diatas dapat diketahui posisi area dengan intensitas cahaya yang rendah, sedang hingga tinggi dengan melihat range angka dari hasil pengukuran, range angka tersebut akan dikelompokkan menjadi 3 himpunan dengan penjabaran sebagai berikut:

1. Himpunan Intensitas cahaya intensitas rendah : range 10.00 - 19.00 lux

2. Himpunan cahaya intensitas sedang : range $20.00-29.00$ lux

3. Himpunan cahaya intensitas tinggi : range $30.00-39.00$ lux

Sehingga diperoleh visual kontur iluminasi dari hasil pengukuran tingkat intensitas cahaya pada ruang utama Masjid Syamsul Ulum sebagai berikut: 

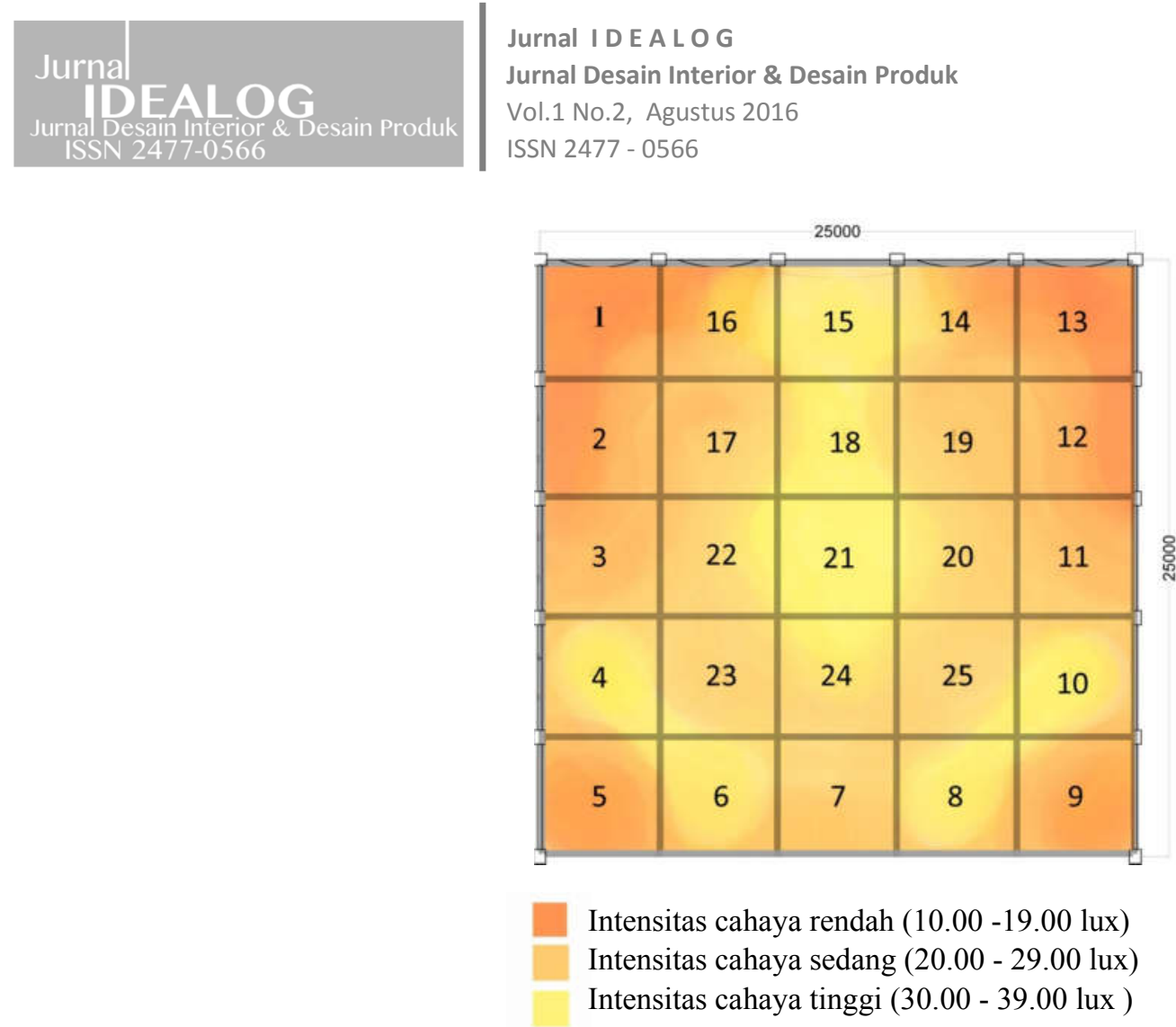

Gambar 6.kontur iluminasi pada titik pengukuran (sumber : pribadi)

\section{Temuan}

Dari hasil observasi lapangan dan wawancara terhadap pengguna mengenai kenyamanan visual melalui pencahayaan buatan pada Masjid Syamsul Ulum Telkom University ditemukan bahwa:

1. Himpunan cahaya dengan intensitas rendah hingga sedang banyak terdapat pada titik dengan fokus kegiatan visual spesifik, sebagai berikut:

- Himpunan intensitas cahaya rendah terdapat pada titik 1,2,5,9,12 dan 13

- HImpunan intensitas cahaya sedang terdapat pada titik 3, 7 dan 11

Sementara itu area pada ruang utama jamaah laki-laki yang diprioritaskan untuk kegiatan sholat mendapatkan intensitas pencahayaan sedang dan tinggi dengan range nilai 20.00 39.00 lux, namun tetap berada dibawah standar kenyamanan pencahayaan bangunan yang telah ditentukan yait 200 lux untuk ruang ibadah dan 250-300 lux untuk kegiatan visual spesifik seperti membaca dan menulis.

2. Kenyamanan visual melalui pencahayaan buatan ditentukan melalui renderasi warna dari colour temperature yang dihasilkan elemen lampu. Dalam menentukan kenyamanan visual, semakin rendah kebutuhan penerangan dari cahaya lampu, maka colour temperature (CT) yang diterapkan makin rendah (warm white), sebaliknya semakin tinggi kebutuhan penerangan, colour temperature (CT) yang diterapkan semakin tinggi 
(cool white). Sementara itu berdasarkan dokumentasi lapangan yang diperoleh melalui proses wawancara dan observasi menunjukkan kesan pencahayaan pada keseluruhan ruang utama jamaah laki-lakimenunjukkan colour temperaturewarm light, sehingga untuk menciptakan kenyamanan visual terkait pekerjaan yang lebih spesifik perlu diterapkan colour temperaturecool light dan day lightuntuk penerangan dengan intensitas tinggi pada area kegiatan visual spesifik (localize lighting), contoh jenis lampu yang dapat diaplikasikan seperti lampu HIT atau fluorescent dengan range colour temperature 3300-5300 Kelvin.

3. Berdasarkan studi aktifitas pengguna zona ruang utama jamaah laki-laki dibagi menjadi dua yaitu zona untuk sholat dan zona untuk kegiatan lainnya seperti diskusi dan mentoring yang membutuhkan dua tipe penerangan berbeda yaitu general lightingdengan color temperature day lightdan aksen warm lightpada titik 14-25 (untuk kegiatan sholat). Pengaplikasian localize lightingpada titik 1-13 dengan color temperature cool light.

\section{Kesimpulan}

Dari hasil observasi diketahui bahwa tipe pencahayaan yang digunakan masjid Syamsul Ulum merupakan tipe general lighting, sementara itu jenis aktifitas di dalamnya seperti membaca dan menulis membutuhkan tipe localize lighting. Setelah dilakukan wawancara dan observasi objek penelitian mulai dari pengukuran menggunakan luxmeter, jenis lampu, dimensi ruang hingga material dan ambiance yang ditimbulkan dalam ruangan, menunjukkan bahwa pencahayaan buatan pada ruang utama jamaah laki laki berada pada kondisi dibawah standar penerangan bangunan dan memiliki colour temperature warm lightsecara keseluruhan.

Hasil pengukuran tingkat penerangan yang diperoleh menggunakan luxmeterbelum sesuai dengan syarat penerangan bangunan berdasarkan SNI-03-6575-2001 tentang Tata Cara Sistem Pencahayaan Buatan pada Bangunan Gedung,sementara itu standar penerangan yang direkomendasikan untuk tempat ibadah sebesar 200 lux dan area belajar/bekerja sebesar 250-300 lux.

Rekomendasi untuk memberi kenyamanan visual pada aktifitas membaca dan menulis adalah merancang tipe pencahayaan setempat (localize lighting) pada area bekerja visual spesifik yang membutuhkan intensitas cahaya lebih tinggi dengan colour temperature cool light. Sementara itu untuk area sholat tetap dapat menggunakan tipe pencahayaan merata (general lighting) dengan color temperature warm lightyang menjadi aksen dengan tetap menggunakan colour temperature cool lightsebagai renderasi cahaya utama. 


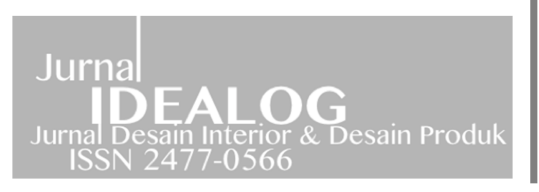

\section{Daftar Pustaka}

[1] Bahri, S., 2007, Evaluasi dan Perbaikan Kondisi Kenyamanan Pencahayaan pada Ruang Ibadah Masjid, Skripsi, Program Studi Teknik Fisika, Institut Teknologi Bandung.

[2] Benya, James Robert. 2006. Sumber-Sumber Cahaya, Dasar-Dasar Pencahayaan. PT Erlangga :Jakarta Timur.

[3] Diyarsyah, Elta. 2008. Studi Kondisi Kenyamanan Visual Ruang Ibadah Masjid Dengan Pencahayaan Alami Dan Gabungan, Skripsi, Program Studi Teknik Fisika, Institut Teknologi Bandung.

[4] DKM Syamsul Ulum. Proposal Pembangunan Masjid Syamsul Ulum, Bandung. 2013.

[5] Latifah, Nur Laela. 2015. Fisika Bangunan 2. Griya Kreasi : Jakarta Timur.

[6] Neufret, Peter.1996. Artificial Lighting and Daylight, Neufret. PT Erlangga :Jakarta Timur.

[7] SNI 03-6575-2001. 2001. Tata Cara Perancangan Sistem Pencahayaan Buatan pada Bangunan Gedung.

[8] Thojib, Jusuf. \& Satya, Muhammad. Kenyamanan Visual Melalui Pencahayaan Alami Pada Kantor, Jurnal Ruas, vol. 11 (2013) No. 2. 